\title{
EVALUATION OF PHYSICO CHEMICAL CHARATERISTICS OF SILK FIBRES OF Litsea cubeba Pers., REARED ON DIFFERENT HOST PLANTS
}

\author{
Faizah Hamzah ${ }^{1}$ \\ ${ }^{I}$ Fakultas Pertanian Jurusan Budidaya Program THP-UNRI, Pekanbaru
}

\begin{abstract}
The golden-yellow silk fibres obtained from Litsea cubeba Pers., westwood reared on leaves of three different host plants belonging to the family Lauraceous, were studied to evaluate their characteristic physico - chemical properties. The host plants M. bombycina King, L. cubeba Pers., Juss and $L$. citrate Roxby, significantly influenced silk length, width, sericin and amino acid contents of the fibres. The contents of the predominant amino acid; glycine $(10.55 \mu \mathrm{g})$, aspartic $(5.43 \mu \mathrm{g})$ and $(7.15 \mu \mathrm{g})$, were higher in fibres obtained from cocoons of $L$. cubeba Pers., fed on $M$. bombycina, while alanine $(9.46 \mu \mathrm{g})$ was higher in the fibres of cocoons obtained from the two host plant. The breaking load $(17.191 \mathrm{~g})$ and tenacity $(3.562 \mathrm{~g})$ were higher in cocoons from the host plant $L$. cubeba Pers. The X-ray diffraction patterns showed the amorphous nature of the fibres obtained from the cocoons of $L$. cubeba Pers., fed on $L$. polyantha and L. citrate while fibres obtained from cocoons from M.bombycina showed amorphous bands with little tendency to two dimensional order. Above all, the natural golden yellow hue of the fibre, which is one of the most important and commercially valuable added properties of this particular silk variety, was better retained in the fibres extracted from cocoons of L. cubeba Pers., larvae reared on M. bombycine.
\end{abstract}

Keywords : amino acids, breaking load, L. cubeba Pers., tenacity, x-ray diffraction

\section{INTRODUCTION}

The muga silk worm, L. cubeba Pers., Westwood, a multivoltine, serico genic insect native to North Eastern India, is generally fed leaves of woody tress like $M$. bombycine King, L. polyantha, L. citrate Roxy, L. salcifolia Roxy and many other host plants produce variable effects on the relative survival of herbivorous insects by influencing food intake, digestion and assimilation which directly affect the larval growth and development ${ }^{[1]}$. Variation in total haemocyte counts (THC), blood volume (BV), body water (BW) content, head capsule widths and body weights L. cubeba Pers., were induced by host plants and seasons of the year ${ }^{[2,3]}$.

Besides affecting variability in biology and physicology of L. cubeba Pers., ${ }^{[4]}$, the host plants influences spectaculary the colour pattern of silk cocoons of L. cubeba Pers., ${ }^{[5]}$. Further, it is known that L. polyantha induces fecundity, whereas, $M$. bombycina improves the amount of silk production ${ }^{[6]}$. Though seasonal variation of cocoon characters of $L$. cubeba Pers., reared on $M$. bombycina has reported available on physical[7], no reports about physico-chemical properties of silk fibres are obtained by rearing worms on different host plants. The mechanism of cocoon fibre formation, structure of sericin and fibroin, and chemical compositions in different sericogenous insects like Bombyx mori, A. yamani, philosomia ricini have been studied ${ }^{[8]}$. In the present paper, were report the phenomenal changes in the physical and physico - chemical properties of silk fibres obtained from cocoons of L. cubeba Pers., reared on three different host plants : $M$. bombycina, L. polyantha and L. citrata.

\section{MATERIAL AND METHOD}

The tree species $M$. bombycina, L. polyantha, L. citrata, L. cubeba Pers., were naturally grown 3-3 years old plants. The trees were 
individual covered by mosquito proof nets, before brushing newly hatched larva into them.

Throughout the larva period, the trees were covered in order to protect the larva from trees were covered in order to protect the larva from predator. Branches of dry leaves of $M$. bombycina were provided at the base of the respective host plants inside the net for cocooning. After 6 days, cocoons were collected for various analyses during the autumn brood ${ }^{[2]}$. Weights of cocoons and pupae were taken in an electronic microbalance (Mittler AE 240 dual range, Mettler instruments AG, Switzerland; sensitivity $0.01 \mathrm{mg}$ ), by following standard degumming and spinning techniques ${ }^{[6]}$, lengths of silk threads per cocoon were measured by employing an emprowvette. Subsequently denier was also calculated. Sericin were measured by the procedure of Jolly and Krishnaswamy ${ }^{[9]}$ and Borah et al., ${ }^{[7]}$. For determination of amino acids, silk fibres were hydrolysed by $6 \mathrm{~N} \mathrm{HCL}$ at $110^{\circ} \mathrm{C}$ for $22 \mathrm{~h}$, taking proper precautions to conserve methionine, cystine and tyrosine. Following digestion 80,40 and $40 \mu \mathrm{g}$ of silk fibres obtained from larvae fed on L. cetrata, $L$. polyantha and $M$. bombycina, respectively, were analysed in a Pharmacia LKB alphaplus amino-acid analyser. Individual amino-acid were quantified as $\mu \mathrm{g} / 100 \mu \mathrm{g}^{[10]}$. For X-ray and infrared (IR) analyses, fibres were made into a powder that posed through a $60-$ mesh sieve. $\mathrm{X}$-ray diffraction data were collected using a controlled X-ray diffractometer (Type JDV - II P3A, JOEL, Japan) with pulse height analyser and scintillation counter with an $\mathrm{Nal}$ (TI) single crystal scientillator.

IR spectra were recorded in a Perkin Elmer Spectrometer (Model 2000 FTIR), using the $\mathrm{KBr}$ disk technique, from 4000 to $400 \mathrm{~cm}^{-1}$ with resolution of $2 \mathrm{~cm}^{-1}$ and a resolution of 2 $\mathrm{cm}^{-1}$ and five scans per sample. Scanning electron micrographs of fibre sample were in a JOEL JSM-35 M-35 CF electron microscope at an accelerating potential of $15 \mathrm{KV}$. Fibre sample obtained from the cocoons reared on the three different host plants were prepared and then mounted on the specimen holders of the electron microscope, with electron conductive tape. The sample were coated with gold in an ion-sputter coater (JFC 100, JOEL,
Japan) in a vacuum to give a layer $150-200 \mathrm{~nm}$ thick before making observations.

\section{Testing of fibres strength properties}

The fibres were conditioned at $65 \%$ relative humidity at for $27^{\circ} \mathrm{C}$ for $2 \mathrm{~h}$ and then tested for various physical properties ${ }^{[11,12]}$.

\section{RESULTS AND DISCUSSION}

Larvae fed on M. bombycina and L. polyantha produced golden-hued cocoons. Whereas those fed on $L$. citrate produced creamy-white cocoons. However, cocoons obtained from $M$. bombycina and $L$. polyantha different distinctly in colour pattern, the farmer were deep golden yellow and shiny, white the latter were dull.

The weights of cocoon, pupae, shell and silk a long with silk length, silk ratio and denier are presented in Table 1. All data were subjected to complete randomized design analysis of variance (ANOVA). Means were compared by the least significant difference (LSD) procedure ${ }^{[13]}$. Cocoons produced by larvae fed on $M$. bombycina were significantly heavier than those fed on L. polyantha and L. citrate, the trend was exactly, similar for shell and silk weight and also for silk length. However, there were no significant difference between pupae weight and silk ration. Sericin content was highest in the fibres obtained from cocoons produced by feeding on $M$. bombycina The fibroins showed variation in amino-acid composition depending on the host plant (Table 2). Alanine and glycine contents were highest in the fibres obtained from larvae fed on M. bombycine (L. cubeba Pers.), and the fibroin was similar to mulberry silk ${ }^{[14,15]}$. Table gives the rations of major amino-acids in the fibroins of $L$. cubeba Pers., in relation to the oust plants.

The physical strength properties of fibres of different denier are given in Table 4. The breaking load of fibres extracted from cocoons from $M$. bombycina was the highest. The cocoon fibres obtained from L. polyantha and $L$. citrate showed higher elongation than from cocoons of M. bombycina (L. cubeba Pers.). 
Table 1. Variation Cocoon Characters of $L$. cubeba Pers., per Produced by Larvae Fed on Different Host Plants

\begin{tabular}{|c|c|c|c|c|}
\hline Properties & $\begin{array}{l}\text { L. cubeba Pers., } \\
\text { (M. bombycina) }\end{array}$ & L. polyantha & L. citrata & P. 0.05 \\
\hline Weight of cocoon $(\mathrm{g})$ & $\begin{array}{c}4.463 \pm 0.32^{\mathrm{a}} \\
(10)\end{array}$ & $\begin{array}{c}3.450 \pm 0.23^{\mathrm{b}} \\
(10)\end{array}$ & $\begin{array}{c}3.765 \pm \\
0.16^{\mathrm{ab}}(10)\end{array}$ & $\mathrm{LSD}=0.7271$ \\
\hline Pupa & $4.531 \pm 0.36$ & $3.732 \pm 0.40$ & $3.495 \pm 0.21$ & NS \\
\hline Shell & $\begin{array}{c}0.359 \pm 0.01^{\mathrm{a}} \\
(10)\end{array}$ & $\begin{array}{c}0.247 \pm 0.04^{b} \\
(10)\end{array}$ & $\begin{array}{c}0.274 \pm 0.01^{b} \\
(10)\end{array}$ & $\mathrm{LSD}=0.0799$ \\
\hline Silk & $\begin{array}{c}0.256 \pm 0.02^{\mathrm{a}} \\
(5)\end{array}$ & $\begin{array}{c}0.086 \pm 0.01^{\mathrm{b}} \\
(5)\end{array}$ & $0.106 \pm 0.02^{\mathrm{b}}(5)$ & $\mathrm{LSD}=0.0584$ \\
\hline Silk length (m) & $441.74 \pm 26.25^{\mathrm{a}}$ & $\begin{array}{c}310.16 \pm \\
3595^{\mathrm{b}}\end{array}$ & $258.54 \pm 30.80^{\mathrm{b}}$ & $\mathrm{LSD}=108.03$ \\
\hline Silk ratio $\mathrm{C} \%$ & $7.39 \pm 0.62$ & $\begin{array}{l}5.52 \pm 42 \\
(10)\end{array}$ & $7.20 \pm 0.38(10)$ & NS \\
\hline Sericin & $23.18 \pm 1.07^{\mathrm{a}}$ & $17.50 \pm 1.07^{b}$ & $18.82 \pm 1.12^{\mathrm{b}}$ & $\mathrm{LSD}=3.76$ \\
\hline
\end{tabular}

Table 2. Amino Acid Content in Silk Fibres of $L$. cubeba Pers., (in $\mu / 100 \mu g$ )

\begin{tabular}{lccc}
\hline Amino acid & $\begin{array}{c}\text { L. cubeba } \text { Pers., } \\
(\text { M. bombycina })\end{array}$ & L. polyantha & L. citrata \\
\hline Aspactic acid & 5.45 & 5.16 & 5.57 \\
Thereonine & 1.17 & 1.53 & 1.49 \\
Serine & 7.15 & 6.53 & 6.43 \\
Glutamic acid & 1.62 & 1.77 & 1.90 \\
Proline & 0.29 & 0.39 & 0.49 \\
Glycine & 10.55 & 9.28 & 7.81 \\
Alinine & 9.46 & 11.32 & 10.40 \\
Cysteine & 0.07 & 0.06 & 0.10 \\
Valine & 0.44 & 0.04 & 0.48 \\
Isoleucine & 0.32 & 0.36 & 0.32 \\
Leucine & 0.47 & 0.50 & 0.47 \\
Tyrosine & 0.10 & 5.38 & 5.92 \\
Phenylalanine & 0.49 & 0.59 & 0.57 \\
Histidine & 1.45 & 1.32 & 1.54 \\
Lysine & 0.34 & 0.48 & 0.40 \\
Arginine & 3.51 & 2.95 & 3.64 \\
\hline
\end{tabular}

Table 3. Ratio of Major Amino-Acids in Fibroins of $L$. cubeba Pers., in Relations to Host Plants

\begin{tabular}{lccc}
\hline Ratio & $\begin{array}{l}\text { L. cubeba } \text { Pers., } \\
(\text { M. bombycina })\end{array}$ & L. polyantha & L. citrate \\
\hline Alanine : Glycine & 0.89 & 1.22 & 1.33 \\
Tyrosine : Serine & 0.85 & 0.82 & 0.98 \\
Aspartic : Arginine & 1.54 & 1.75 & 1.53 \\
\hline
\end{tabular}


Table 4. Physical Strength Properties of $L$. cubeba Pers., Silk Fibres from Silk Cocoons of Different Host Plants*)

\begin{tabular}{lccc}
\hline Physical & $\begin{array}{l}\text { L. cubeba } \text { Pers., } \\
(\text { M. bombycina })\end{array}$ & L. polyantha & L. citrate \\
\hline Denier & 5.270 & 3.390 & 3.640 \\
Breaking load (g) & 17.791 & 10.443 & 11.287 \\
Elongation (\%) & 19.564 & 24.160 & 25.942 \\
Tenacity (g/d) & 3.562 & 2.415 & 2.460 \\
\hline${ }^{*}$ Results are means of three readings & & &
\end{tabular}

The IR absorption bands displayed all the characteristic for groups present in different amino acid. The bands between $3070 \mathrm{~cm}^{-1}$ and $3100 \mathrm{~cm}^{-1}$ were due to $\mathrm{NH}$ - stretching of secondary amides, $1660 \mathrm{~cm}^{-1}$ being. The Co absorption band of amide I. The amide II band of primary amides comes from the scissoring motion of $\mathrm{NH}_{2}$ at $1650-1620 \mathrm{~cm}^{-1}$ and of the secondary amide at $1550-1500 \mathrm{~cm}^{-1}$. The amide III bands appeared in the secondary amides between 1310 and $1200 \mathrm{~cm}^{-1}$ come from the mixed vibration in $\mathrm{C}-\mathrm{N}$ stretching and $\mathrm{N}-\mathrm{H}$ bending ${ }^{[16]}$. On the whole, the absorption bands displayed characteristic groups of the amino acids that were present in the L. cubeba Pers., silk protein.

The X-ray diffraction patterns of silk fibres of L. cubeba Pers., extracted from cocoons produced on $M$. bombycina (L. cubeba Pers.), $L$. polyantha and $L$. citrate did not show the orderly $3-D$ crystal lattice. However, fibres of $L$. cubeba Pers., obtained from cocoons of $M$. bombycina fed larvae exhibited amorphous bands with little tendency to $2-\mathrm{D}$ order. Such a pattern was lacking in the other two samples and they were similar in from. That the fibroin molecule contains non-repetitive (amorphous fraction) and repetitive (crystalline fraction) amino acid sequences in several conformations of different stability ${ }^{[15]}$ was exhibited in the present samples.

\section{CONCLUSIONS}

The importance and popularity in India of the silk fibre from $L$. cubeba Pers., particularly in the North Eastern region of the country is due to its natural golden yellow (muga in Asamese) colour. L. cubeba Pers., a polyphagous saturniidae, is being traditionally reared out door on the naturally grown host plant $L$. cubeba Pers., (M. bombycina) for commercial silk production. It is now established that the host plant for L. cubeba Pers., larvae has a significant affect not only on the natural golden yellow colour of the fibre but also on its physical strength properties.

\section{REFERENCES}

1. G. P. Waldbauer, The Consumption and Utilization of Food by Insects, Advances in Insect Physiology, 5, 1999, 229 - 288.

2. S. Bordoloi, L. K. Hazarika, Seasonal Variations of Body Weight, Lipid Reserves, Blood Volumes and Hemocyste Population of L. cubeba Pers, Environmental Entomology, 20(6): 13981403, (2002).

3. L. K. Hazarika, S. Borbodoi, A. Kataky, Effects of Host Plant on Haemocyte Populations and Blood Volume of $L$. cubeba Pers West Wood, Sericologia, 34(2): 310-306, (2002).

4. A. Kataky, L. K. Hazarika, and B. G. Unni, Biochemical Analysis of L. cubeba Pers and its Host Plants. $61^{\text {st }}$ Animal General Meeting. Society for Biological Chemist (India). Centre for Cellular and Molecular Biology Hydrabad 21-23 December 2002.

5. S. N. Chondhury, Muga Silk Industry, $1^{\text {st }}$ ed, Directorate of Sericulture Assam, India, 2001.

6. S. N. Chondhury, Silk and Sericulture, $1^{\text {st }}$ ed, Directorate of Sericulture Assam, India, 2002.

7. A. Borah, S. N. Phukan, M. V. Samson Variation in Cocoons Characters of $L$. cubeba Pers During Different Seasons 
Scricologia, 28: 215-218, (2003).

8. K. Komatsu, Chemistry and Structure of Silk JARQ, 1999, 13(1): 64-72.

9. M. S. Jolly, S. Krishnaswanny, Sericin Content in Cocoon of Indigenous Silk Worm Races (Bombimory L) Indian, $J$. of Sericulture, 111(1): 17-18, (2003).

10. A. Kataky, and L. K. Hazarika, Effect of Host Plant on Certain Biological and Physiological Variable, of L. cubeba Pers., in Proceedings of Recent Advances in Life Science, Vol. 1 ed A.K. Rai, Dibrugarth University, India, 19-24, (2002).

11. J. E. Boath, Principles of Textile, $3^{\text {rd }}$ ed, Butter Worth Scientific, London, 1999.

12. American Society for Testing Material, Standard Test Methods for Tensile Properties of Single Textile Fibre Vol. 7
ASTM S1776 USA, 2002.

13. K. A. Gomez and A. A. Gomez, Statistical Procedures for Agricultural Research, $2^{\text {nd }}$ ed, Wilwy, New York, 2002.

14. R. S. Dhavalikar, Amino-Acid Composition of Indian Silk Fibroin and Sericins; Part I Fibroins, J. Sci and Ind. Res Zic., 10: 261 - 263, (1990).

15. F. Schnal, H. Akai, Insect Silk Glands: Their Type Development and Function and Effect of Environ Mental Factors, and Morphogenetic Hormones on Then, Int J. of Insect Morphology and Embryology, 19(2): 79-132, (2003).

16. F. S. Parker, Applications of Infrared Spectroscopy in Biochemistry, Biology and Medicine, Plenum Press, New York, 2001. 